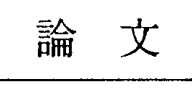

\title{
Effects of stand structure on growth in selection stands dominated by todo fir (Abies sachalinensis)
}

\author{
Satoshi Tatsuhara* ${ }^{*}$ Hirokazu Yamamoto ${ }^{* *}$, \\ Norikazu TAKADA ${ }^{* *}$ and Hiroshi INUGAI ${ }^{* *}$
}

\begin{abstract}
Tatsuhara, Satoshi, Yamamoto, Hirokazu, Takada, Norikazu and Inugal, Hiroshi : Effects of stand structure on growth in selection stands dominated by todo fir (Abies sachalinensis). Jpn. J. For. Plann. 25:17 25, 1995 This paper examines the relationship between growth and stand structure in selection forests dominated by todo fir (Abies sachalinensis (FR. SCHMIDT) MASTERS). Trees were classified into six classes by their species (conifers or broad-leaved trees) and diameter (small, medium or large trees). A principal component analysis showed that the six class volumes were well summarized by the first two principal components obtained from the class volumes. The first principal component contrasted the volume of small and medium-sized conifers with the volume of large conifers and broad-leaved trees. The second principal component contrasted the volume of medium and large conifers with the volume of large broad-leaved trees. Next, a multiple regression analysis showed that there were correlations of net increment, gross increment and mortality with the principal components; and the relationships between stand volume growth and six class volumes were shown numerically. The first principal component reflected a constant effect (i.e., independent of time since selection cutting) of stand structure on volume growth and the second principal component reflected the effect depending on selection cutting. In conclusion, selection stands with many medium-sized conifers grew more than stands containing fewer medium-sized conifers or than stands containing more trees assigned to other classes; and large conifers suppressed stand volume growth less if the selection cutting cycle was short.
\end{abstract}

龍原 哲・山本博一・高田功一・犬飼 浩：トドマツ主体の択伐林において林分構造が 成長に与える影帮 森林計画誌 $25: 17$ 25, 1995 本研究ではトドマツ主体の択伐林 における林分構造と成長の関倸を調べた，最初に，林木を樹種と胸高值径によって6つに 分類した，樹種は針葉樹と広葉樹に，胸高值徍は小径級，中径級，大径級に分類した，主 成分分析によって 6 種類の材積は第一主成分と第二主成分によって表現できることが示さ れた。第一主成分は小中径針葉樹の材積と大径木の材積の差を表しており，第二主成分は 中大径針葉樹の材積と大径広葉樹の材積との差を表している。次に，重回帰分析によって 林分材積の純成長量, 粗成長量, 枯損量が二つの主成分と相関を持つことが示され，林分 材積の成長と 6 種類の材積との関係が数量的に示された。第一主成分は林分棈造が材積成 長に与える影響を安定的に示しており，第二主成分はこの影篭が択伐によって変動するこ とを示していた，以上の結果から，中径針葉樹が多い択伐林は材積成長量が大きく，また， 回帰年が短ければ大径木もあまり材積成長を抑制しないことが導かれた。

\section{Introduction}

Relationships between growth and stand structure in natural stands are important when managing uneven-aged stands for selective harvesting (selection stands). However, it is difficult to understand the relationships because the structure of natural stands is complex and their growth process depends on the stands themselves, as analyzed and reported by TAKEUCH et al. $(1980,1981)$

* Fac. of Agric., the Univ. of Tokyo. Tokyo 113 東京大学農学部

** University Forest in Hokkaido, the University of Tokyo, Furano, Hokkaido 079-15 東京大学北海道演習林 
and Ishibashi (1990). They, however, classified trees in natural stands into two species classes or three diameter classes. Because these factors in natural stands are dependent, a mutual relationship (i. e., if one factor increases, the others decrease) between them should be taken into consideration.

Most of the Tokyo University's Hokkaido Forest is covered with natural forest that is mainly selectively cut. The most important species for timber products is todo fir (Abies sachalinensis (FR. SchmidT) Masters). Therefore, this paper reports analysis of relationships between growth and stand structure in the selection stands dominated by todo fir. Trees are classified into six classes by their species and diameter.

\section{Data}

The study area, the Hokkaido Forest, is located in the Pan mixed forest zone $\left(43^{\circ} \mathrm{N}, 142^{\circ} \mathrm{E}\right)$ between

Table 1. List of experimental plots.

\begin{tabular}{|c|c|c|c|c|}
\hline Plot code & Year of plot establishment & Compartment & Subcompartment & Area (ha) \\
\hline 5001 & 1963 & 87 & a & 0.398 \\
\hline 5002 & 1959 & 86 & $\mathrm{f}$ & 0.360 \\
\hline 5004 & 1959 & 36 & c & 0.480 \\
\hline 5005 & 1961 & 86 & $\mathrm{~b}$ & 0.325 \\
\hline 5006 & 1961 & 36 & $b$ & 0.348 \\
\hline 5007 & 1963 & 84 & $\mathrm{a}$ & 0.333 \\
\hline 5101 & 1958 & 51 & a & 0.250 \\
\hline 5102 & 1958 & 51 & a & 0.250 \\
\hline 5103 & 1958 & 51 & a & 0.250 \\
\hline 5104 & 1958 & 51 & a & 0.250 \\
\hline 5105 & 1960 & 57 & $\mathrm{~b}$ & 0.418 \\
\hline 5107 & 1959 & 64 & $\mathrm{a}$ & 0.750 \\
\hline 5110 & 1960 & 103 & $\mathrm{~b}$ & 0.370 \\
\hline 5111 & 1960 & 103 & $\mathrm{~b}$ & 0.436 \\
\hline 5113 & 1959 & 101 & $\mathrm{a}$ & 0.571 \\
\hline 5115 & 1961 & 106 & $\mathrm{~b}$ & 0.398 \\
\hline 5116 & 1961 & 102 & $\mathrm{a}$ & 0.415 \\
\hline 5124 & 1963 & 109 & $\mathrm{a}$ & 0.345 \\
\hline 5137 & 1969 & 51 & a & 0.376 \\
\hline 5138 & 1969 & 51 & $\mathrm{a}$ & 0.242 \\
\hline 5139 & 1970 & 61 & $\mathrm{~b}$ & 0.514 \\
\hline 5144 & 1972 & 99 & a & 0.995 \\
\hline 5202 & 1960 & 24 & a & 0.286 \\
\hline 5204 & 1958 & 31 & $\mathrm{~b}$ & 0.492 \\
\hline 5206 & 1929 & 24 & $\mathrm{c}$ & 0.301 \\
\hline 5207 & 1929 & 24 & $\mathrm{c}$ & 0.295 \\
\hline 5208 & 1929 & 24 & $\mathrm{c}$ & 0.301 \\
\hline 5209 & 1929 & 24 & $\mathrm{c}$ & 0.392 \\
\hline 5212 & 1961 & 26 & $\mathrm{~d}$ & 0.351 \\
\hline 5213 & 1961 & 18 & $\mathrm{e}$ & 0.375 \\
\hline 5216 & 1963 & 25 & $\mathrm{~b}$ & 0.324 \\
\hline 5219 & 1969 & 25 & $\mathrm{a}$ & 0.146 \\
\hline 5220 & 1969 & 25 & $\mathrm{c}$ & 0.231 \\
\hline 5243 & 1980 & 25 & c & 0.300 \\
\hline $5304-2$ & 1960 & 58 & a & 0.498 \\
\hline $5304-3$ & 1960 & 58 & $\mathrm{a}$ & 0.500 \\
\hline
\end{tabular}


the cool-temperate and the sub-boreal zone. The Hokkaido Forest is divided into two working circles, the "first" and the "second", which differ in management of the selection stands. In the first, the selection cutting cycle is ten years and the ratio of selection cutting is $16 \%$ (i. e., $16 \%$ of the stand's trees are removed in each selection cut). In the second, the selection cutting cycle is 20 years and the ratio of selection cutting is $20 \%$. Data analyzed in this study were taken on 36 permanent plots in the first circle's selection stands. Years of plot establishment and their areas are shown in Table 1. Generally, they have been measured every four years, plus when the stands containing them were selectively cut. Diameters at breast height $(\mathrm{DBH})$ were measured on all trees whose diameters were $\leq 5.0 \mathrm{~cm}$.

Although the plots contain many species, todo fir predominates and comprises most of conifers. Conifers occupy $40 \%$ to $90 \%$ in terms of both stocking and stand volume. The main broadleaved trees in the plots were Japanese linden (Tilia japoinca (MIQ.) SIMONKAI), painted maple (Acer Mono MAXIM. subsp. marmoratum (NICHOLSON) KitAmURA), monarch birch (Betula Maximowicziana REGEL), white oak (Quercus mongolica FISCHER et Turez. var. grosseserrata), and caster aralia (Kalopanax pictus (THUNB.) NAKAI).

\section{Analyses}

\section{Principal component analysis for stand structure}

Trees were classified into six classes by their species and diameter. The species classes were conifers and broad-leaved trees. The diameter classes (small trees, medium trees and large trees), are used for management in the Hokkaido Forest and Hirata et al. (1987) showed validity of this classification for describing stand structure. Size ranges of diameter class are : small ( 5 to 25 $\mathrm{cm})$, medium $(25$ to $39 \mathrm{~cm})$ and large $(>39 \mathrm{~cm})$.

Tree volumes were estimated from their DBHs by the following equations :

$$
\begin{aligned}
& v=d^{2.45935 / 6814.2425,} \\
& v=\left\{\begin{array}{l}
d^{2.4189} / 6086.9537(d \leq 76) \\
0.19 d-8.62(d>76)
\end{array}\right.
\end{aligned}
$$

where $v\left(\mathrm{~m}^{3}\right)$ is volume and $d(\mathrm{~cm})$ is DBH. Eq. (1) is for conifers and Eq. (2) is for broad-leaved trees. These equations were obtained by fitting to local volume tables used in the Hokkaido Forest. Volumes for the six classes were calculated by summing volumes of individual trees. Volumes per hectare were used as original variables in the analysis below.

A principal component analysis for the six original variables yielded Table 2 . The first principal component explained $49.0 \%$ of the total variance. Together, the first two principal components explained $77.7 \%$ of the total variance, well summarizing variation of the original. Eigenvectors corresponding to the eigenvalues of the principal components are shown in Table 3 . Values of the first two principal components are given in Fig. 1. The first principal component's values ranged from -133.8 to 129.9 and those of the second from -147.6 to 73.1 . Table 4 shows average

Table 2. Eigenvalues of the covariance matrix.

\begin{tabular}{crcc}
\hline Principal component & Eigenvalue & Proportion $(\%)$ & Cumulative(\%) \\
\hline 1 & 3588.59 & 49.0 & 49.0 \\
2 & 2093.37 & 28.6 & 77.7 \\
3 & 1281.14 & 17.5 & 95.2 \\
4 & 166.84 & 2.3 & 97.4 \\
5 & 132.58 & 1.8 & 99.3 \\
6 & 54.54 & 0.7 & 100.0 \\
\hline
\end{tabular}


Jpn. J. For. Plann. 25 '95

Table 3. Eigenvectors.

\begin{tabular}{lrrrrrr}
\hline \multicolumn{1}{c}{ Variable } & 1 & 2 & 3 & 4 & \multicolumn{1}{c}{5} & \multicolumn{1}{c}{6} \\
\hline Small conifers & -0.2180 & 0.0847 & -0.2198 & 0.8339 & -0.4017 & 0.2006 \\
Medium-sized conifers & -0.6487 & -0.2037 & -0.6413 & -0.3491 & -0.0672 & -0.0051 \\
Large conifers & 0.3126 & -0.9352 & -0.0904 & 0.1358 & -0.0261 & 0.0187 \\
Small broad-leaved trees & 0.0771 & -0.0007 & 0.0975 & -0.2898 & -0.2382 & 0.9186 \\
Medium-sized broad-leaved trees & 0.1446 & 0.0160 & 0.0965 & -0.2809 & -0.8806 & -0.3394 \\
Large broad-leaved trees & 0.6380 & 0.2764 & -0.7165 & -0.0378 & 0.0356 & 0.0200 \\
\hline
\end{tabular}

Table 4. Average values of the principal components.

\begin{tabular}{lccrrrrr}
\hline \multicolumn{1}{c}{ Attribute } & $\begin{array}{c}\text { Number of } \\
\text { measurements }\end{array}$ & 1 & 2 & 3 & 4 & 5 & 6 \\
\hline Just after cutting & 35 & -1.215 & 5.435 & 12.253 & 2.501 & -0.411 & -0.891 \\
Others & 81 & 0.525 & -2.349 & -5.294 & -1.081 & 0.177 & 0.385 \\
\hline
\end{tabular}

Table 5. Results of multiple regression analysis concerning effect of the first two components on net increment.

\begin{tabular}{lcrlccc}
\hline \multicolumn{1}{c}{ Attribute } & Term & $\begin{array}{c}\text { Regression } \\
\text { coefficient }\end{array}$ & F-ratio & $\begin{array}{c}\text { Partial correlation } \\
\text { coefficient }\end{array}$ & $\begin{array}{c}\text { Correlation } \\
\text { coefficient }\end{array}$ & $\begin{array}{c}\text { Multiple correlation } \\
\text { coefficient }\end{array}$ \\
\hline \multirow{2}{*}{ Just after cutting } & $a_{1}$ & -0.02562 & $9.94^{* *}$ & -0.487 & -0.447 & 0.519 \\
& $a_{2}$ & -0.01728 & 3.06 & -0.295 & -0.207 & \\
\multirow{2}{*}{ Others } & $a_{0}$ & 6.24936 & & & & \\
& $a_{1}$ & -0.03302 & $17.27^{* *}$ & -0.426 & -0.414 & 0.445 \\
& $a_{2}$ & 0.01732 & 2.60 & 0.179 & 0.143 & \\
Total & $a_{0}$ & 5.34455 & & & & \\
& $a_{1}$ & -0.03026 & $23.65^{* *}$ & -0.416 & -0.415 & 0.422 \\
& $a_{2}$ & 0.00714 & 0.88 & 0.082 & 0.075 & \\
\hline
\end{tabular}

** Significant at the 0.01 level of probability.

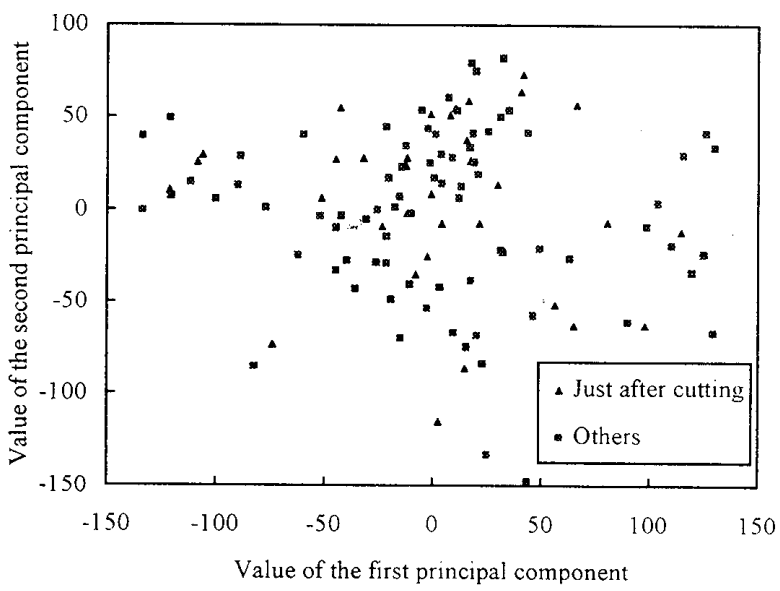

Fig. 1. Relationships between values of the first two principal components.

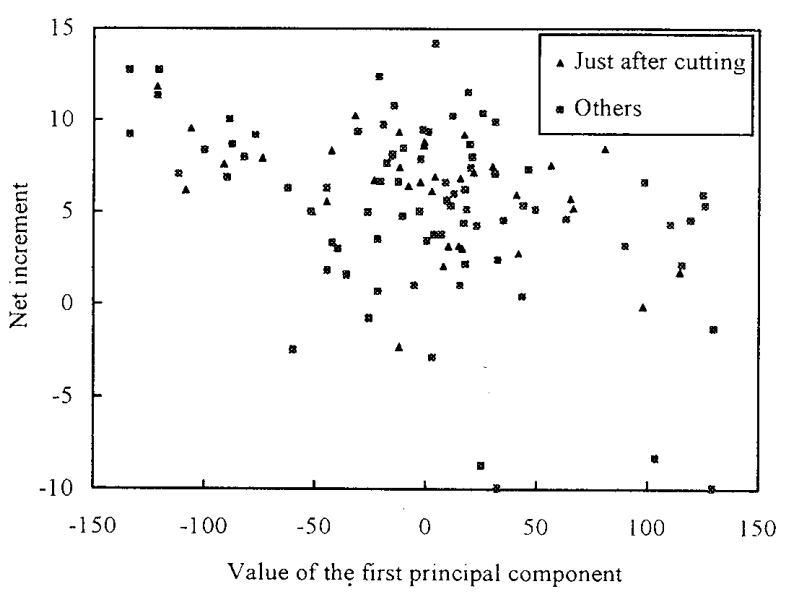

Fig. 2. Relationships between value of the first principal component and net increment. 
values of the principal components for data collected from open stands just after cutting and data from other stands whose canopies were clos. ing (data collected a few years after selection cutting).

\section{Multiple regression analysis for growth and the principal components}

Mean annual net increment, mean annual mortality and mean annual gross increment were calculated in terms of volume from each stand's data. To analyze the relationship between stand growth and stand structure, the linear regression model

$$
Y=a_{0}+a_{1} C_{1}+a_{2} C_{2}
$$

was selected, where $Y$ is response, $C_{1}$ is value of the first principal component, $C_{2}$ is value of the second principal component, and ai $(i=0,1,2)$ are coefficients. The model was fitted to three groups of data: data collected just after selection cutting, other data collected a few years after selection cutting (from stands whose canopies were closing) and both combined.

Fitting the model to the net increment and values of the principal components data yielded Table 5. Net increment correlated negatively with the first principal component's value in all three groups. Fig. 2 shows their relationships. However, there was low negative correlation between net increment and the second principal component's value in the data collected just after selection cutting, low positive correlation in the other data and, consequently, little correlation in the combined data. That is to say, the first principal component affected net increment constantly (i. e., independent of time since selection cutting), while the second principal component had less effect on net increment than the first principal component and affected net increment differently in stands just after selection cutting and other stands a few years after selection cutting.

Fitting the model to the mortality and principal components data yielded Table 6. There were positive correlations between mortality and the first principal component's value in all three groups. Fig. 3 shows their relationship. However, there was little correlation between mortality and the second principal component's value in the data collected just after selection cutting, low negative correlation in the other data and, consequently, low negative correlation in the combined data. That is to say, the first principal component affected mortality constantly while the second principal component had less effect on mortality than the first principal component and had little effect in stands just after selection cutting.

Fitting the model to the gross increment and

Table 6. Results of multiple regression analysis concerning effect of the first two components on mortality.

\begin{tabular}{lcccccc}
\hline \multicolumn{1}{c}{ Attribute } & Term & $\begin{array}{c}\text { Regression } \\
\text { coefficient }\end{array}$ & F-ratio & $\begin{array}{c}\text { Partial correlation } \\
\text { coefficient }\end{array}$ & $\begin{array}{c}\text { Correlation } \\
\text { coefficient }\end{array}$ & $\begin{array}{c}\text { Multiple correlation } \\
\text { coefficient }\end{array}$ \\
\hline Just after cutting & $a_{1}$ & 0.008426 & 2.88 & 0.288 & 0.275 & 0.297 \\
& $a_{2}$ & 0.004081 & 0.46 & 0.119 & 0.079 & \\
\multirow{2}{*}{ Others } & $a_{0}$ & 1.45121 & & & & \\
& $a_{1}$ & 0.01819 & $7.83^{* *}$ & 0.302 & 0.288 & 0.345 \\
\multirow{2}{*}{ Total } & $a_{2}$ & -0.01564 & 3.16 & -0.197 & -0.175 & \\
& $a_{0}$ & 2.41953 & & & & \\
& $a_{1}$ & 0.01522 & $9.51^{* *}$ & 0.279 & 0.276 & 0.308 \\
& $a_{2}$ & -0.009939 & 2.37 & -0.143 & -0.138 & \\
& $a_{0}$ & 2.16328 & & & & \\
\hline
\end{tabular}

** Significant at the 0.01 level of probability. 
principal components data yielded Table 7. Gross increment correlated negatively with the first principal component's value in all three groups. Fig. 4 shows their relationships. However, there was a low negative correlation between gross increment and the second principal component's value in the data collected just after selection cutting, little correlation in the other data and, consequently, little correlation in the combined data. That is to say, the first principal component affected gross increment constantly while the second principal component had less effect on gross increment than the first principal component and affected gross increment only in stands just after selection cutting.

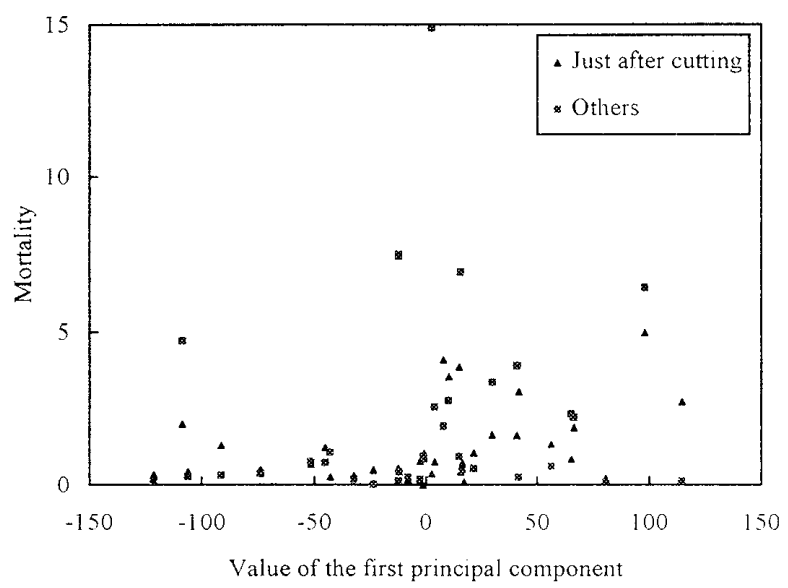

Fig. 3. Relationships between value of the first principal component and mortality.
A third principal component, $C_{3}$, was added, yielding the linear regression model

$$
Y=a_{0}+a_{1} C_{1}+a_{2} C_{2}+a_{3} C_{3}
$$

which was applied to the three data group. However, correlation coefficients of the model improved little.

\section{N. Discussion}

Variation of the selection stands' six class volumes is well summarized by the two principal components, $C_{1}$ and $C_{2}$ as follows:

$$
\begin{aligned}
C_{1}= & -0.2180 V_{s c}-0.6487 V_{m c}+0.3126 V_{l c} \\
& +0.0771 V_{s b}+0.1446 V_{m b}+0.6380 V_{l b}
\end{aligned}
$$

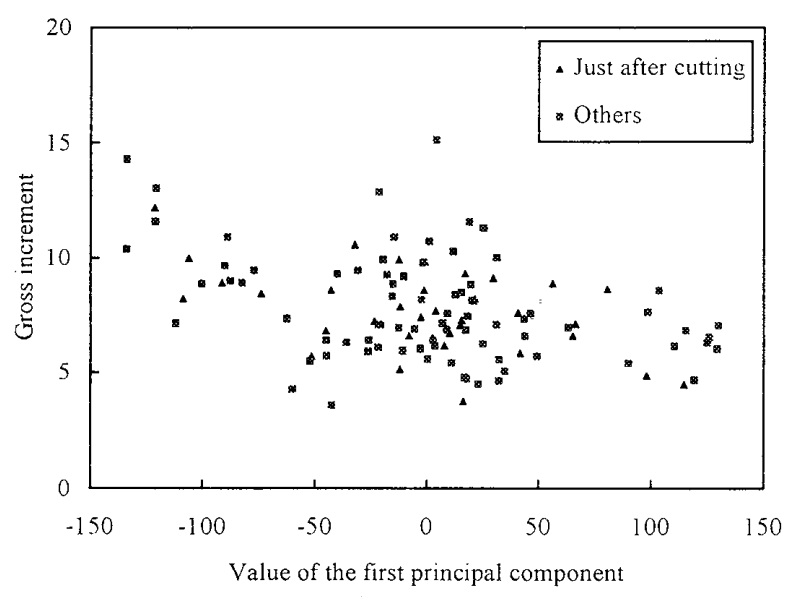

i Fig. 4. Relationships between value of the first principal component and gross increment.

Table 7. Results of multiple regression analysis concerning effect of the first two components on gross increment.

\begin{tabular}{lcccccc}
\hline \multicolumn{1}{c}{ Attribute } & Term & $\begin{array}{c}\text { Regression } \\
\text { coefficient }\end{array}$ & F-ratio & $\begin{array}{c}\text { Partial correlation } \\
\text { coefficient }\end{array}$ & $\begin{array}{c}\text { Correlation } \\
\text { coefficient }\end{array}$ & $\begin{array}{c}\text { Multiple correlation } \\
\text { coefficient }\end{array}$ \\
\hline Just after cutting & $a_{1}$ & -0.01719 & $13.88^{* *}$ & -0.550 & -0.492 & 0.595 \\
& $a_{2}$ & -0.01325 & 5.56 & -0.385 & -0.272 & \\
\multirow{2}{*}{ Others } & $a_{0}$ & 7.70253 & & & & \\
& $a_{1}$ & -0.01483 & $14.16^{* *}$ & -0.392 & -0.392 & 0.392 \\
\multirow{3}{*}{ Total } & $a_{2}$ & 0.001666 & 0.10 & 0.035 & 0.013 & \\
& $a_{0}$ & 7.76430 & & & & \\
& $a_{1}$ & -0.01504 & $23.30^{* *}$ & -0.414 & -0.413 & 0.417 \\
& $a_{2}$ & -0.002822 & 0.48 & -0.065 & -0.059 & \\
\hline
\end{tabular}

** Significant at the 0.01 level of probability. 


$$
\begin{aligned}
C_{2}= & 0.0847 V_{s c}-0.2037 V_{m c}-0.9352 V_{l c} \\
& +0.0007 V_{s b}+0.0160 V_{m b}+0.2764 V_{l b}
\end{aligned}
$$

where $V_{s c}, V_{m c}, V_{l c}, V_{s b}, V_{m b}$, and $V_{l b}$ were volumes of small, medium and large conifers and broad-leaved trees, respectively. The first principal component, $C_{1}$, contrasts the volume of small and medium-sized conifers with the volume of large conifers and broad-leaved trees. The second principal component, $C_{2}$, contrasts the volume of medium and large-sized conifers with the volume of large broad-leaved trees. Small and mediumsized broad-leaved trees had little effect on the principal components.

This analysis revealed that the first principal component had a constant effect on growth of selection stands dominated by todo fir and its value was negatively correlation with growth. This means that small and especially mediumsized conifers increased selection volume growth while large conifers and broad-leaved trees decreased it. Conversely, the second principal component's effect on selection stand growth changed with time after selection cutting; its value was negatively correlated with growth just after cutting and positively correlated with growth later at canopy closure. The second principal component was affected mainly by large-conifer volume. Open stands with a greater volume of large conifers grew more just after cutting, because in the six classes large conifers grew most and in the open stands shaded small and medium-sized trees less. They did, however, suppressed small and medium-sized trees as their canopies closed. Thus, stands with closing canopies and greater volumes of large conifers grew less than other stands. Fig. 5 shows the largest growth areas in the selection stands. As stand canopies close, the area moves as shown. The effects of stand structure on growth depend on canopy closure, also meaning that large conifers

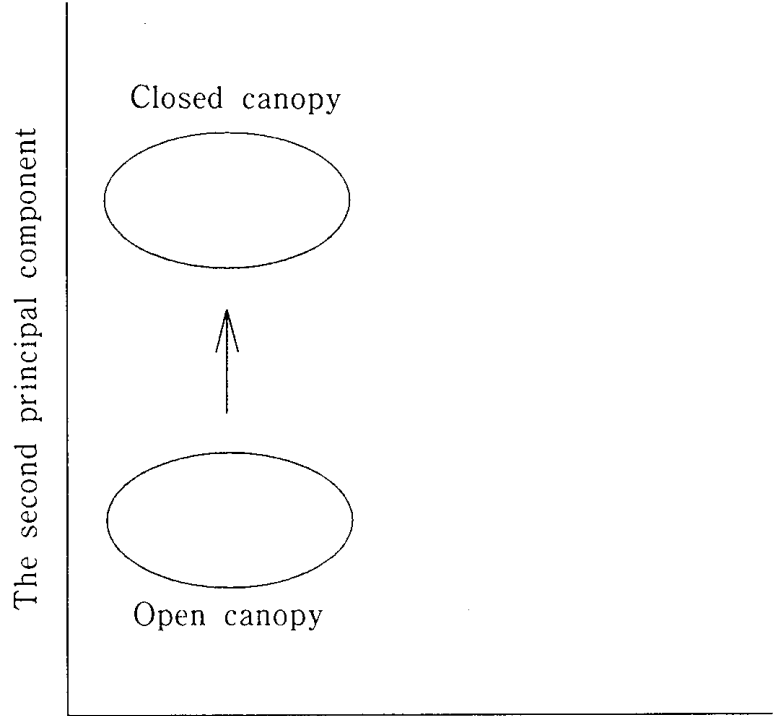

The first principal component

Fig. 5. The largest growth areas in the selection stands.

Note; The ellipses show the areas where the selection stands reflect the greatest amount of growth

do not suppress stand volume growth if those stands are allowed to open.

TAKEUCHI et al. (1980) reported that conifers grew more than broad-leaved trees in natural forests and the highest growth rates occurred in stands where growth was concentrated in the conifers. Ishibashi (1990) reported that stands with high volumes of conifers grew more than stands with low conifer volumes. Furthermore, TAKEUCHI et al. (1981) reported that selection stand growth depended mainly on growth of small and medium-sized trees in the first working circle and ISHIBASHI (1990) reported the same in other kinds of natural forests. They observed a relationship between growth and each factor of species and diameter class volume. In this paper the data were analyzed by the principal components of the factors of species and diameter class volumes and our results agree with their reports.

ISHIBASHI and HIROKAWA (1986) stated that gross increment of natural forests varied even though they had the same stand volume, that it had maximum and minimum distribution curve and 
that the maximum distribution curve culminated at stand volume of $300 \mathrm{~m}^{3} / \mathrm{ha}$. They explained forest and stand growth and mortality with a distribution graph. Net increment, however, decreased with the value of the first principal component (Fig. 2) ; gross increment also decreased with its value, though the difference between minimum and maximum values was less than net increment (Fig. 3). Though mortality was scattered more widely than net increment and gross increment, it tended to increase with the first principal component's value as in Fig. 3. Based on these analyses, general dynamics of the first working circle's selection stands are summarized in Fig. 6. A selection stand moves down and to the right as it grows, which means that growth itself decreases in a selection stand as the number and volume of large conifers and broad-leaved trees increase and the stand canopy closes. It moves up and to the left if it is selectively cut. This means that large trees are harvested mainly by selection cutting, which increases growth in selection stands. It can be moved in any direction by mortality, depending on the resulting change of stand structure. For example, it moves

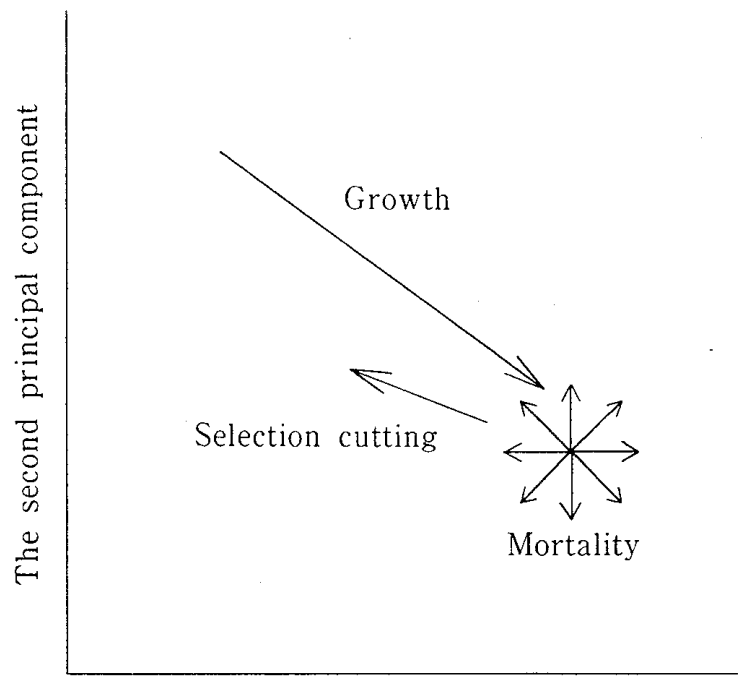

The first principal component

Fig. 6. General dynamics of selection stands in the Hokkaido Forest. to the left if large trees die and to the right if medium-sized conifers die.

\section{Conclusion}

Stand structure of selection stands was explained by two principal components obtained from the volume of six classes by their species and diameter. Growth was observed to correlate with the principal components, i. e., the relationship between stand volume growth and the six class volumes were shown numerically. The first principal component reflected a constant effect of stand structure on volume growth and the second principal component reflected the effect depending on selection cutting. These results led to conclusion that selection stands with more volume in medium-sized conifers grew more than stands containing fewer medium-sized conifers or than stands containing more trees assigned to the other classes; and, that large conifers suppressed stand volume growth less if the selection cutting cycle is short.

In this paper, the relationship between volume growth and stand structure was shown for selection forest management. Lumber value, however, was not concerned. Value growth is important for management, too. Thus, determining optimum stand structure for selection forest management requires additional study to examine relationships between value growth and stand structure.

\section{Literature cited}

Hirate, Y., Ishibashi, S. and TAKADA, K. (1987) An analysis of data on selection forest in the Tokyo University Forest in Hokkaido (III) Diameter grouping. Trans. Mtg. Kanto $\mathrm{Br}$. Jpn. For. Soc. 39: 19 22. (Only in Japanese) ISHIBASHI, S. (1990) Studies on the structural dynamics of natural forest based on a simulation model. Bull. Tokyo Univ. For. 82:11 101. (in Japanese with English summary) 
ISHIBASHI, S. and HIROKAWA, T. (1986) An analysis of data on selection forest in the Tokyo University Forest in Hokkaido. Trans. Mtg. Kanto Br. Jpn. For. Soc. 37: 15 18. (Only in Japanese)

Takeuchi, K., Hirokawa, T. and Kawahara, S. (1981) The growth of selection forest in the Tokyo University Forest in Hokkaido (VI) A comparison of three diameter classes in volume growth. Trans. Mtg. Jpn. For. Soc. 92 : 91 92. (Only in Japanese)

Takeuchi, K., Kawahaka, S. and Hirokawa, T. (1980) The growth of selection forest in the Tokyo University Forest in Hokkaido (V). Trans. Mtg. Jpn. For. Soc. $91: 73 \sim 74$. (Only in Japanese)

(Received November 4, 1994) 